\title{
EMPACT OF THE AGGREGATION PHEROMONE TRAPS BAITED WITH FERMENTED FOOD MATERIALS ON THE ATTRACTION OF THE RED PALM WEEVIL, Rhynchophorus ferrugineus (OLIVIER) IN EGYPT
}

\author{
ABBAS, M.K.A. ${ }^{1}$; M.A. EL-DEEB'; ${ }^{2}$ M.M. EL-ZOHAIRY ${ }^{2}$ and OLFAT E. ARAFA $* 1$. \\ 1. Plant Protection Res. Inst., ARC, Dokki, Giza, Egypt. \\ 2. Plant Protection Dept., Fac. Agric., Zagazig Univ., Egypt. \\ ${ }^{*}$ Corresponding author: Tel.: +201207176937 \\ E-mail address: olfatelsayed@yahoo.com
}

(Manuscript received 6 August 2018)

\begin{abstract}
$\mathrm{T}$ he aggregation pheromone traps of the red palm weevil, Rhynchophorus ferrugineus (Olivier, RPW) is an essential method for integrated pest management in field trials. Experiments were carried out on date palm plantations at (Abo-Nagi) El-Kassasein district, Ismailia Governorate, Egypt during one year (2012). Three baited pheromone traps with different food materials were tested. Adding date fruits to pheromone was the best bait to attract RPW where the number of weevils captured was 1005 adults representing $41.75 \%$ of the total catch compared to sugarcane and pheromone, which caught 807 adults, represented $33.53 \%$ of the total catch. Traps with ethyle acetate caught the least number 595 adults representing $24.72 \%$ of the total catch. The obtained results obviously indicated that numbers of captured adults were high significantly increased in traps supplied with dates than other food materials. Accordingly it is recommended to add date fruits to the pheromone traps. Generally, to achieve more capturing effectiveness of aggregation pheromone traps helping in controlling red palm weevil, it is necessary to use traps with holes and funnel without cover and placed at ground and supplied with fermented date fruits.
\end{abstract}

Keyword: Rhynchophorus ferrugineus (Olivier), pheromone traps, dates, sugarcane.

\section{INTRODUCTION}

The red palm weevil, Rhynchophorus ferrugineus (Olivier) (Order: Coleoptera, Family: Curculionidae) was first recorded in Egypt in date palm plantations at Sharkia and Ismailia Governorates by Saleh (1992).

Eggs are laid in the leaf petioles of date palm trees. Hatching larvae (grubs) enter the tunnel through the soft wood of the heart of the trunk and feed voraciously causing destruction of the palm where they complete their life cycle. Many generations can be passed throught in the same palm tree. Therefore, neither grubs nor damage caused can be directly seen. By time, a brownish viscous liquid can be seen oozing from small holes in the trunk of the tree. Often, the attack by the weevil is only discernible when the palm has been extensively damaged.

The aim of the study was to evaluate the attraction of the weevil by different fermented materials to assess the most effective ones. 


\section{MATERIAL AND METHODS}

\section{Attraction of the weevil to different fermented materials}

At El- Kassasein district (Abo-Nagi), Ismailia Governorate, 5 faddans in which date palm trees were extensively distributed was chosen for one year (2012) experminte, nine pheromone traps were randomly distributed where the distance between each two traps was $100 \mathrm{~m}$. The experimental design was a randomized complete blocks design and the trap shape (holes and funnel without cover) at height on ground level placed near 5 date palm tree trunks. Varieties being, Zaghloul, Hayani, Samani, Bent-Esha and Amry.Attracting of fermented substances were tested and three replicates for each attraction for pheromone only and two fermented matters.A total of 9 traps were placed for the trapping period from 1/1/2012 until 31/12/2012 (Fig.1).

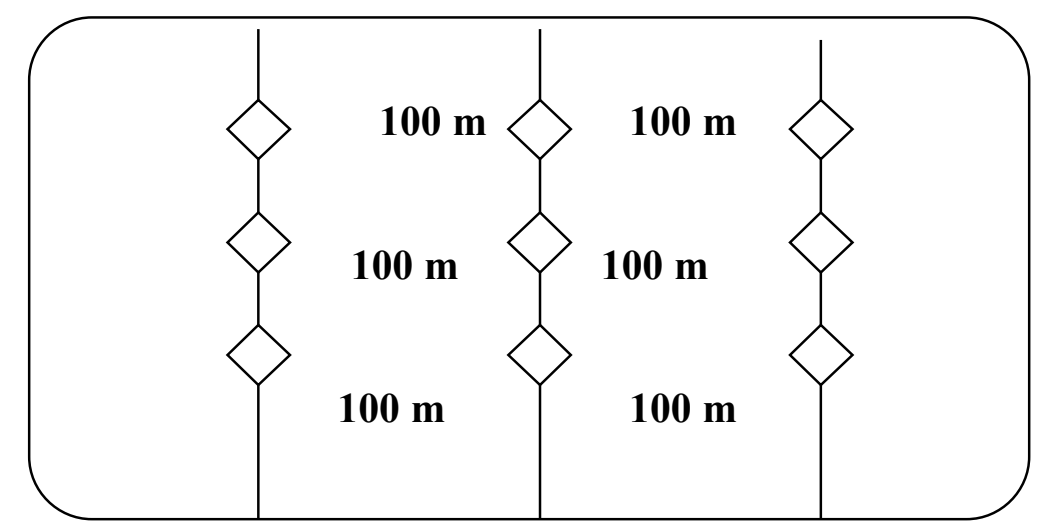

Fig.1.A diagram showing the distribution of aggregation pheromone traps in date palm orchard at El-Kassasein district, Ismailia Governorate

The experimental design was a complete randomized blocks design with three treatments of fermented types (type 1: ethyl acetate (kairomone) and pheromone, type 2: sugarcane cubes and pheromone and type 3:Fruit dates and pheromone) using three replicates in each treatment, traps were sited on ground surface. Changes in the population density were determined by numbers of captured $R$. ferrugineus adults based on aggregation pheromone traps in selected area. The number of collected weevils caught in the pheromone traps was counted weekly and sexed. Kairomone (ethyl acetate) and pheromone capsules in each trap were renewed every 15 days, while the soap water solution was renewed weekly.

\subsection{Trap type description:}

The used traps common were the plastic buckets ( 9 liters in size). The bucket was punctured around its wall with four holes each of $2.5 \mathrm{~cm}$ in diameter at $15 \mathrm{~cm}$ 
from the bottom applying funnel without cover $8 \mathrm{~cm}$ in diameter on the top of bucket traps and placed on ground surface (Fig. 2).

funnel
pheromone

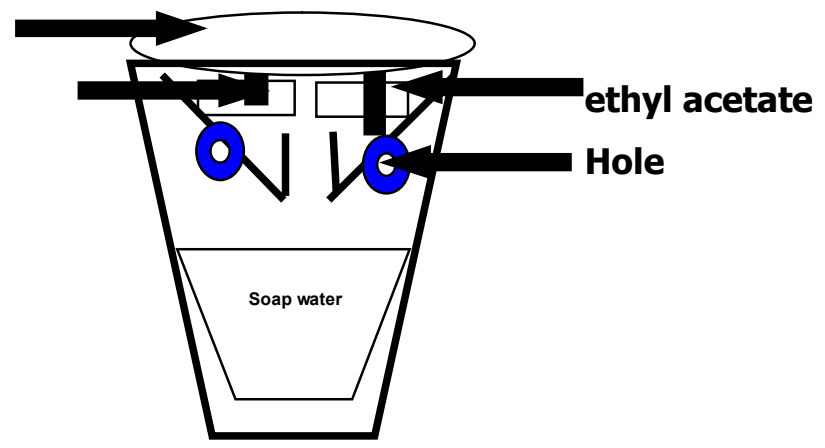

Fig. 2. Diagramm of trap type 1

\subsection{Synthetic aggregation pheromone lures:}

The commercially used pheromone "PO28 Ferrolure+" is a synthetic pheromone lure, (a mixture of 4-methyl-5-nonanol and 4-methyl-5-nonanone (9:1). Purity of both $>95 \%$. Components used were imported from ChemTica International S.A., Costa Rica. Pheromone sac was hanged on the underside of trap top surface. The pheromone releases its active chemicals blames through a plastic membrane. Release Rate (3-10 mg /day). Minimum $700 \mathrm{mg} /$ lure total mixture from 400 and 1500 $\mathrm{N} /$ tube, Bubble formulation one lure per pack. Colorant and stabilizer added. Respectively under laboratory conditions of $27^{\circ} \mathrm{C}$ and $50 \%$ R.H. under identical conditions. (Hallet, et al., 1993).

Selected Kairomone was used as a synergist to activate the potent ability of releasing ethyl acetate blooms. However, ethyl acetate bags were hanged from the underside surface of the trap top releasing chemicals through a fine plastic tube (as 100 and $128 \mathrm{mg} / \mathrm{d}$ ).

\subsection{Ethyl acetate (Kairomone) and pheromone:}

1 liter water, $5 \mathrm{~g}$ yeast and Emix insecticide 35\% S.C. (6-chloro-3-pyridytmethyl) $\mathrm{N}$ - nitroimidazalidin- $\mathrm{z}$ ylideneamine). Adult weevils captured in traps were removed, counted and sexed weekly.

\subsection{Sugarcane cubes and Pheromone:}

Sugarcane cubes were 15 pieces $10 \mathrm{~cm}$ lenghth impressed for 24 hrs in aqueous solution of $5 \mathrm{~g}$ yeast suspended in 1 liter of water. Pieces were dipped for 3 minutes in the tested insecticide solution (Emix, 35\% S.C.which mentioned above).

\subsection{Fruit dates and pheromone:}

An amount of $500 \mathrm{gs}$ of date fruits were impressed for $24 \mathrm{hrs}$ in an aqueous solution of $5 \mathrm{~g}$ yeast suspended in 1 liter of water. Then were dipped for 3 minutes in 
insecticide solution (Emix, 35\%S.C. which mentioned above). The poisoned bait (sugarcane stem, dates fruits and insecticide) was changed weekly oweing to its dehydration. Ethyl acetate kairomone and pheromone capsules within each trap were replaced by another new fresh one monthly.

\subsection{Killing materials}

Liquid soap was mixed with trap water and used inside the bucket trap.

\section{Statistical Analysis}

The obtained results were statistically analysed using a computer program at Costat, Correlation (S.A.S., 1985).

\section{RESULTS AND DISCUSSION}

\section{Effect of weevil attraction by different fermented materials:}

\subsection{Evaluation of the efficiency of pheromone traps supplied with food materials}

Data in Table (1) and illustrated by Fig. (3) present the weekly numbers of both adult sexes captured in baited traps supplied with different food materials and with aggregation pheromone placed in date palm tree orchards in Abo-Nagi farm, Elkassassein district, Ismailia Governorate, during 2012 season.

\subsubsection{Food types}

Adding date fruits to pheromone was the best bait to attract RPW where the number of weevils captured was 1005 adults representing $41.75 \%$ of the total catch compared to sugarcane stem and pheromone, which caught 807 adults represented $33.53 \%$ of the total catch. Traps with ethyle acetate caught the least number 595 adults represening $24.72 \%$ of the total catch.

Data agreed with Faleiro and Satarkar (2005) who reported that addition of food bait helped maintained the trapping efficiency of the pheromone lure. Kalleshwaraswamy et al. (2006) reported the lowest numbers of weevils captured in traps where no food bait was used and Al-Saoud (2007) found that the number of RPW captured in the 16 traps was 1752 insects for pheromone and dates but 181 insects for pheromone alone with significant differences approximately 10 to 32 times, respectively. Results disagreed with Muralidharan et al. (1999) who found significant number of weevils of RPW attracted to bucket pheromone traps baited with sugarcane, followed by coconut excerpt. Date fronds were the least preferred bait. The capture rate was reduced by trapping by $75.17 \%$ within 3 years. Abbas (2000) confirmed that sugarcane stem plus pheromone was the best bait to attract RPW showing 677 adults ( $35.19 \%$ of the total catch) compaired with 256 adults (13.31\%) for pheromone only. Faleiro and Satarkar (2002) found that the highest weevil 
captures were recorded when pineapple was used as food bait (12.22 weevils per trap), followed by sugarcane (7.7 weevils per trap). Weevil captures declined to 59.06 per pineapple and 26.71 sugarcane. The same authors (2005) found that oil palm fruit proved to be poor bait for RPW as it adversely affected the efficiency of the pheromone trap. Kalleshwaraswamy et al. (2006) stated that the highest weevil capture could be obtained if pineapple was used as food bait with lure in synthetic aggregation pheromone lure. Oehlschlager (2007) described new natural food bait, ethyl acetate and moist that is more effective than sugarcane in capture of $R$. palmarum in pheromone traps. Al-Saoud (2011) found that date palm pieces caught the least number (23.8) of weevils per trap.

\subsubsection{The population and sex ratio relatively to food materials:}

Results in Table (1) revealed that the highly number of males of weevils was recorded in traps with dates 1005 (404 or representing 40.20\% and $601 \%$ representing $59.80 \%$ of total captured) followed by steem sugarcane 807 (348 $0^{\text {T }}$ representing $43.12 \%$ and $459 \%$ representing $56.88 \%$ ) and the least number was recorded during pheromone only 595 (240 or representing $40.34 \%$ and $355 \%$ representing $59.66 \%$ ).

Data agree with Soroker et al. (2005) who recommended traps with ferrugineol pheromone supplemented with ethyl acetate and a fermenting mixture of dates to monitor weevil infestation and reduce the RPW populations by mass trapping. The sex ratio of trapped adults during 3 years of study was significantly female-biased (2.5:1). Al-Saoud and Aziz Ajlan (2013). Results disagreement with that obtained by Posado and Aaran (1991), Rajamanickam et al. (1995), Abbas (2000), El-Sebay (2003), Kalleshwaraswamy et al. (2006), Muthiah and Nair (2007), Al-Saoud (2011) and AlSaoud (2013) . 
72 EMPACT OF THE AGGREGATION PHEROMONE TRAPS BAITED WITH FERMENTED FOOD MATERIALS ON THE ATTRACTION OF THE RED PALM WEEVIL, Rhynchophorus ferrugineus (OLVIER) IN EGYPT

Table 1. Monthly average number of $R$. ferrugineus (Oliv.) adults captured in nine pheromone funnel traps, without cover and with four holes top with food attractive material (dates, sugarcane and ethyl acetate) placed on ground level in date palm orchard at Abo-Nagi farm,El-Kassassein, Ismailia Governorate during 2012 season.

\begin{tabular}{|c|c|c|c|c|c|c|c|c|c|c|c|c|c|c|c|}
\hline Food attractive materials & \multicolumn{5}{|c|}{ Traps with dates } & \multicolumn{5}{|c|}{ Traps with steam of sugarcane } & \multicolumn{5}{|c|}{ Traps with ethyle acetate } \\
\hline \multirow[t]{2}{*}{ Date } & \multirow{2}{*}{ M. } & \multirow{2}{*}{ F. } & \multirow{2}{*}{ Total } & \multirow{2}{*}{$\%$ of o } & \multirow{2}{*}{\begin{tabular}{|l} 
Accu. \\
No. \\
\end{tabular}} & \multirow{2}{*}{ M. } & \multirow{2}{*}{ F. } & \multirow{2}{*}{ Total } & \multirow{2}{*}{$\begin{array}{c}\% \text { of } \\
0^{\circ}\end{array}$} & \multirow{2}{*}{$\begin{array}{l}\text { Accu. } \\
\text { №. }\end{array}$} & \multirow{2}{*}{ M. } & \multirow{2}{*}{ F. } & \multirow{2}{*}{ Total } & \multirow{2}{*}{$\begin{array}{c}\% \text { of } \\
0^{\circ}\end{array}$} & \multirow{2}{*}{$\begin{array}{c}\text { Accu. } \\
\text { No. }\end{array}$} \\
\hline & & & & & & & & & & & & & & & \\
\hline Jan. & 1 & 2 & 3 & 33.33 & 3 & 3 & 4 & 7 & 42.86 & 7 & 2 & 5 & 7 & 28.57 & 7 \\
\hline Feb. & 5 & 6 & 11 & 45.45 & 14 & 4 & 9 & 13 & 30.77 & 20 & 5 & 5 & 10 & 50 & 17 \\
\hline Mar. & 50 & 65 & 115 & 43.48 & 129 & 28 & 30 & 58 & 48.28 & 78 & 33 & 35 & 68 & 48.53 & 85 \\
\hline April & 59 & 85 & 144 & 40.97 & 273 & 54 & 58 & 112 & 48.21 & 190 & 38 & 40 & 78 & 48.72 & 163 \\
\hline May. & 48 & 57 & 105 & 45.71 & 378 & 49 & 58 & 107 & 45.79 & 297 & 35 & 35 & 70 & 50 & 233 \\
\hline Jun. & 58 & 61 & 119 & 48.74 & 497 & 45 & 56 & 101 & 44.55 & 398 & 33 & 37 & 70 & 47.14 & 303 \\
\hline Jul. & 38 & 53 & 91 & 41.76 & 588 & 33 & 36 & 69 & 47.83 & 467 & 20 & 29 & 49 & 40.82 & 352 \\
\hline Aug. & 21 & 47 & 68 & 30.88 & 656 & 25 & 25 & 50 & 50 & 517 & 11 & 21 & 32 & 34.38 & 384 \\
\hline Sep. & 30 & 68 & 98 & 30.61 & 754 & 30 & 51 & 81 & 37.04 & 598 & 23 & 41 & 64 & 35.94 & 448 \\
\hline Oct. & 26 & 35 & 61 & 42.62 & 815 & 23 & 23 & 46 & 50 & 644 & 10 & 24 & 34 & 29.41 & 482 \\
\hline Nov. & 41 & 75 & 116 & 35.34 & 931 & 30 & 75 & 105 & 28.57 & 749 & 15 & 61 & 76 & 19.74 & 558 \\
\hline Dec. & 27 & 47 & 74 & 36.49 & 1005 & 24 & 34 & 58 & 41.38 & 807 & 15 & 22 & 37 & 40.54 & 595 \\
\hline Total & 404 & 601 & $1005 a$ & & & 348 & 459 & $807 \mathrm{~b}$ & & & 240 & 355 & $595 \mathrm{c}$ & & \\
\hline Mean & 33.67 & 50.08 & 83.75 & & & 29 & 38.25 & 67.25 & & & 20 & 29.58 & 49.58 & & \\
\hline Sex ratio $\%$ & 40.20 & 59.80 & 100 & & & 43.12 & 56.88 & & & & 40.34 & 59.66 & 100 & & \\
\hline S.E. \pm & 5.12 & 5.85 & 10.14 & & & 11.006 & 6.425 & 9.17 & & & 3.61 & 4.74 & 6.82 & & \\
\hline
\end{tabular}
$\mathrm{M}=$ male $\quad \mathrm{F}=$ female $\quad$ Accu. $\%=$ accumulation percentage $\%=$ percentage S.E. $\pm=$ standered error L.S.D. $0.01=0.3201 \quad \mathrm{No}=$ number $\quad \sigma^{2}=$ male

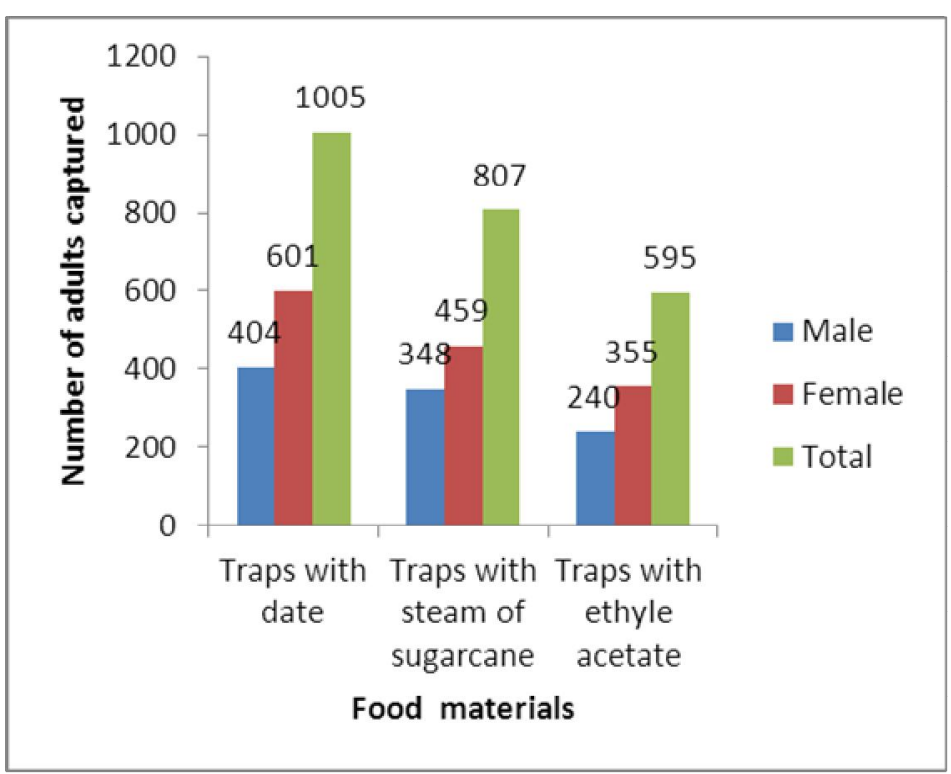

Fig. 3. Number of captured red palm weevil, R.ferrugineus (Oliv.) adults in pheromone traps supplied with dates, sugarcane and ethyle acetate placed in date palm orchard at Abo-Nagi farm, El-Kassassein, Ismailia Governorate during 2012. 


\section{REFERENCES}

1. Abbas, M.K.A. 2000. Studies on the red palm weevil. M. Sc. Thesis, Fac. Agric., Zagazig Univ., 104 pp.

2. Al-Saoud, A.H. 2007. Importance of date fruit in red palm weevil, Rhynchophorus ferrugineus (Olivier) (Coleoptera: Curculionidae) aggregation pheromone traps. In: A. Zaid, V. Hegarty, H.H.S. Al Kaabi (Eds).( Proceeding of $3^{\text {th }}$ Interna. Date Palm Conf. Abu Dhabi, United Arab Emirates. ISHS .Acta Horticulturae, 736: 405-413.

3. ............... 2011. Comparative effectiveness of four food baits in aggregation pheromone traps on red palm weevil, Rhynchophorous ferrugineus (Olivier) .Arab Journal of Plant Protection,29(1): 83-89.

4. ............... 2013. Effect of ethyl acetate and trap colour on weevil captures in red palm weevil, Rhynchophorus ferrugineus (Olivier) (Coleoptera: Curculionidae) pheromone traps. International Journal of Tropical Insect Science, 33(3): 202-206.

5. Al-Saoud, A. H. and A. Ajlan. 2013. Effect of date fruits quantity on the numbers of red palm weevil, Rhynchophorus ferrugineus (Olivier), captured in aggregation pheromone traps. Agriculture and Biology Journal of North America, 4(4):496-503.

6. El-Sebay, Y. 2003. Ecological studies on the red palm weevil, Rhynchophorus ferrugineus Oliv. (Coleoptera: Curculionidae) in Egypt. Egyptian Journal of Agricultural Research, 81 (2): 523-529.

7. Faleiro, J. R. and V. R. Satarkar. 2002. Sustaining trapping efficiency of pheromone traps by periodic replacement of food baits against Red Palm Weevil, Rhynchophorus ferrugineus (Olivier). Resources Management in Plant Protection during twenty first century, Hyderabad, India (14-15 November) Volume II: $124-126$.

8. 2005. Attraction of food baits for use in red palm weevil, Rhynchophorus ferrugineus Olivier pheromone trap. Indian Journal of Plant Protection, 33 (1): 23-25.

9. Hallet, R.H.; G. Gries; R. Gries; J.H. Borden; N.P.D. Angerilli and A. Rauf. 1993. Aggregation pheromone of two Asian palm weevil, Rhynchophorus ferrugineus and R.vulneratus, Naturwissenschaften, 80:328-331.

10. Kalleshwaraswamy, C. M.; P. Jagadish and S. Puttaswamy. 2006. Standardization of food bait, height and colour of the trap for attracting red palm weevil, Rhynchophorus ferrugineus (Olivier) by synthetic pheromone lure. Annals of Plant Protection Sciences, 14 (1): 17-21. 
74 EMPACT OF THE AGGREGATION PHEROMONE TRAPS BAITED WITH FERMENTED FOOD MATERIALS ON THE ATTRACTION OF THE RED PALM WEEVIL, Rhynchophorus ferrugineus (OLVIER) IN EGYPT

11. Muralidharan, C.M.; U.R.Vaghasia and N.N. Sodagar. 1999. Population, food preference and trapping using aggregation pheromone (ferrugineol) on red palm weevil (Rhynchophorus ferrugineus). Indian J. of Agric. Sci. 69 (8): 602604.

12. Muthiah,C. and C.P.R.Nair. 2007. Evaluation of food baits for red palm weevil pheromone traps in coconut.Annals of Plant Protection Sciences, 15(2): 476477.

13. Oehlschlager, A.C. 2007. Optimizing trapping of palm weevils and beetles. Acta Horticulturae, (736): 347-368.

14. Posada,F. and D.F.Aaran. 1991. Population fluctuation and evaluation of baits for the capture of Rhynchophorus palmarum. (Coleoptera: Curculionidae) in African palm. Revista Colombiana de Entomologio, 17 (2): 38-43.

15. Rajamanickam, K.; J.S.Kennedy and A.Christopher. 1995. Certain components of integrated management of the red palm weevil, Rhynchophorus ferrugineus L. (Coleoptera: Curculionidae) on coconut. Wetenschappen Universiteit Gent, 60(3): 803-805.

16. Saleh, M.R.A. 1992. Red palm weevil, Rhynchophorus ferrugineus (Olivier). The first record for Egypt and indeed the African Continent, List No. 10634 Africa, Collection No. 22563. British Museum Report of International Institute of Entomology, 56 Queen's Gate, London, SW 75 JR UK: 1p.

17. S.A.S Institute. 1985. SAS user 's guide: statistics, $5^{\text {th }}$ Ed SAS Institute, Cary, NC.:209-246 pp.

18. Soroker, V.; D. Blumberg ; A. Haberman ; M. Hamburger-Rishard ; S. Reneh; S. Talebaev; L.Anshelevich and A. R. Harari. 2005. Current status of red palm weevil infestation in date palm plantations in Israel Phytoparasitica , 33 (1) : 97-106. 
تأثثر المواد الغذائية المتخمرة على أنجذاب حشرة سوسة النخيل الحمراء إلى المصائد الفيرومونية التجميعية فى مصر

$$
\begin{aligned}
& \text { محمد كمال عبداللطيف عباس 1'، محمد على الايب² }
\end{aligned}
$$

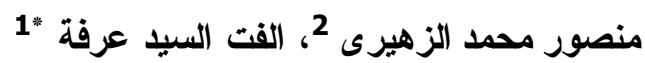

$$
\begin{aligned}
& \text { 1- معهد بحوث وقاية النباتات - مركز البحوث الزراعية - الدقى - الجيزة - مصر . } \\
& \text { 2- قسم وقاية النبات - كلبة الزر اعة - جامعة الزقازيق - مصر. }
\end{aligned}
$$

تعتبر المصائد الفيرومونية التجميعية طريقة ضرورية للمكافحة المتكاملة لسوسة النخيل الحمر اء أجريت تجارب حقلية فى زر اعات نخيل البلح بمنطقة أبوناجى، مركز القصاصين ،محافظة فئه

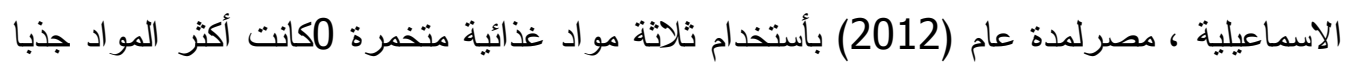

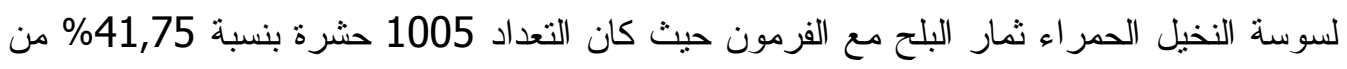
المجموع الكلى للحشرات التى تم أصطيادها مقارنة بعقل قصب السكر و الفرمون حيث أصطادت 807 حشرة بنسبة 33,53\% من المجموع الكلى للحشر ات ـ فى حين أصطادت المصائد المزودة بالاثيل اسيتات أقل عدد من الحشرات 595 بنسبة 24,72\% من المجموع الكلى للحشرات التى عنى نم

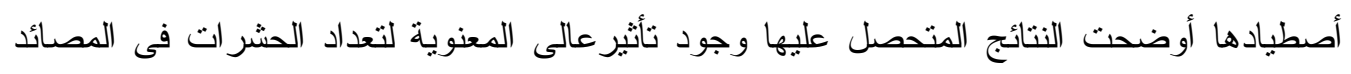

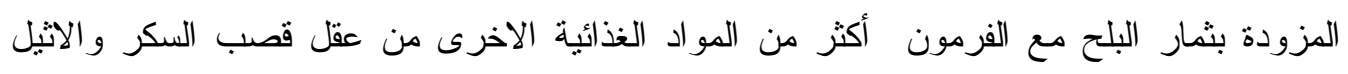

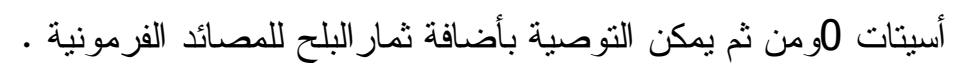
عموماً للحصول على أعلى نأثير للاصطياد بالمصائد الفيرومونية التجميعية لمكافحة سوسة النيلة النخيل

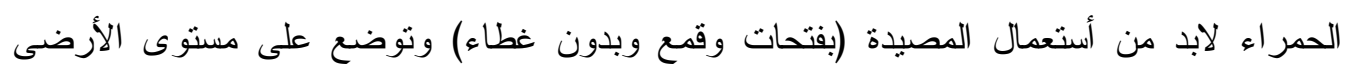
وتزود بثمار البلح المتخمرة. 
